\title{
14 The COVID-19 pandemic, courts, and the justice system
}

\author{
Muna Ndulo, DPhil
}

\section{Introduction}

The COVID-19 pandemic has had a deep impact on communities across the world. The virus has now spread to over 177 countries, and it has affected all aspects of daily life, including the economy, education, healthcare, food security, gender inequality, and the administration of justice. The justice system, which is the focus of this chapter, has faced tremendous challenges. The pandemic has forced courts to limit or end jury trials; restrict access to courtrooms; suspend inperson proceedings; grant extensions for court deadlines (including deadlines to pay fees and fines); and encourage or require audio and video conferences in lieu of in-person hearings. It has also resulted in an increased number of persons held in pre-trial detention all over the world. These challenges raise several questions. First, what are the main challenges to accessing the justice system-especially among women and other vulnerable groups? Second, what measures are courts taking to deal with the current challenges, and what is the potential impact of these measures on the delivery of justice and the protection of human rights? Policymakers need to find meaningful answers to these questions to ensure that policy interventions can guarantee the rule of law and access to justice.

Respect for the rule of law and the protection of individual rights are necessary conditions for sustainable economic and social development. Since an effective and efficient justice system is critical to the promotion of rule of law and good governance, the maintenance of such a system is central to inclusive economic growth. ${ }^{1}$ This is especially important for developing economies that have limited capacity to absorb systemic shocks. The adoption and strengthening of human rights, the deepening of democracy, and the increased public participation in governance all require an effective judicial system. Indeed, the courts play an important role in strengthening democratic institutions responsible for adopting justice-related policies and adequately protecting and promoting human rights. An effective judicial system has been described as "one that is predictable, resolves cases in a reasonable time frame, and is accessible to the public" (Dakolias, 1999, p.87).

Justice systems worldwide provide essential constitutionally mandated services to the public. ${ }^{2}$ They provide countries with mechanisms for people and 
corporations to settle both criminal and civil disputes. They also serve as an instrument for the protection of vulnerable groups in society (Banda, 2019, p.4). An effective, efficient, and well-resourced system of justice should guarantee a fair hearing and manifest equality before the courts. While courts should be impartial and treat everyone equally when settling disputes, there are sometimes vast differences in the experience of members of the public when they engage with the courts. For example, racial and socio-economic inequalities in many parts of the world are abetted and sometimes exacerbated by the inability of the justice system to adequately respond to the needs of minorities and economically disadvantaged groups. Overly difficult procedures can sometimes make judicial institutions inefficient and limit access to judicial services. Even in ordinary times, judicial systems are not perfect. For example, many courts face delays in the resolution of disputes, and some courts struggle with large caseloads as well as inadequate courtrooms and personnel. Delays in criminal trials leave many people in jail awaiting trial for long periods of time, which often leads to overcrowded jails.

The pandemic has exacerbated these challenges as courts prioritize the safety of judges, lawyers, parties, court staff, and members of the public. Court officials are faced with the challenge of balancing the need to minimize health risks with the need to keep the judicial system operational. To prevent and control the potential spread of COVID-19 via the courts, countries have instituted several measures. While the adoption of strict measures is important to curb the spread of the disease, it can also negatively affect the delivery of vital public services. As Texas Chief Justice Nathan Hecht observed with respect to the United States, "Since the onset of the pandemic, courts throughout the country have determined to stay open to deliver justice without faltering, no matter the adjustments and sacrifices demanded, but also to protect staff ... and the public from the risks of disease. We are learning new technology and practices together" (NCSC, n.d.). ${ }^{3}$ At the beginning of the pandemic, courts in most jurisdictions suspended their operations, as many officials thought that the pandemic would be controlled in a few months. Court proceedings were restricted to only urgent cases. For example, many criminal courts only heard pleas for serious cases and bail applications. Even then, they had to comply with state policies on public health. Courts also restricted entry to court buildings to litigants and witnesses only. As time passed and uncertainty around the duration of the pandemic grew, courts began to rearrange the physical layout of their courtrooms to adhere to social distancing and other health measures. Additionally, many resorted to holding proceedings online, which necessitated not only the restructuring of the courts' physical infrastructure but also the upgrading of their information and communication technologies (ICT) infrastructure. As a result of the pandemic, video conferencing and electronic filing have become the default means of conducting court proceedings worldwide. However, this has also lifted the veil on existing problems created by the digital divide and the limited skills and broadband infrastructure in many courts in developing countries. This is exacerbated by the fact that courts in many countries were behind the curve in technology 
adoption even before the COVID-19 pandemic. Dame Hazel Genn, Professor at University College London, observes with respect to the United Kingdom:

The COVID-19 pandemic has necessitated a significant increase in the role of technology in the justice system in England and Wales. The ongoing reform program "Transforming our Justice System," which began in 2016, aimed to radically enhance the role of technology. However, when COVID19 pandemic struck in 2020 the court system was still, in terms of the use of technology, virtually below the sea level.

(Justice Committee, 2020)

One of the most unfortunate results of the COVID-19 pandemic is that it has increased longstanding structural inequalities in society. It is also undermining the progress that has been made in reducing both economic and gender inequality. Moreover, the crisis has made it more difficult for countries to work toward the attainment of the Sustainable Development Goals, as countries have been forced to shift budgetary resources from development priorities to pandemic-related measures. As a result of historical and structural conditions, women have been disproportionately impacted by the pandemic within the household, in the public sphere, and in the courts and the rest of the justice system. The impact of the pandemic on access to judicial services for women and other vulnerable groups is exacerbated by deeply entrenched gender norms and structures. Understanding this structural context is important to determine both the impact of the crisis and the efficacy of policy interventions on women and other vulnerable groups.

This chapter examines the challenges that judicial systems, especially the courts, are facing because of the COVID-19 pandemic. It focuses on the impact of the current crisis on women, mainly in terms of their ability to access courts and the overall justice system, and it evaluates measures taken to ensure that courts are safe and continue to dispense justice and offer effective protection to women and other vulnerable groups. In its concluding section, the chapter looks at whether the crisis brought about by the pandemic provides an opportunity for courts to increase their use of technology to improve their operations. Specifically, the chapter explores the opportunity to improve justice systems by integrating technologies into court proceedings and other judicial services, especially in developing countries. Finally, the chapter considers what post-pandemic courts will look like and what it will take, in terms of resources and infrastructure, to ensure that people, particularly women and other vulnerable groups, have access to fair and efficient judicial services, which will almost certainly require improved capacity for technology.

\section{The challenges posed by the pandemic to the justice system: An overview}

\section{The courts, access to justice, and the COVID-19 pandemic}

The courts, like many other institutions, have been affected by the COVID19 pandemic. Judges, court officials, and lawyers are all among those who have 


\section{Muna Ndulo}

been infected by the virus. Courts exist to ensure that all people have access to judicial services and are protected by a country's laws and regulations. However, the court system is unable to function if there is no access to the courts or other justice forums. The COVID-19 pandemic has forced many countries to introduce sweeping measures to control the spread of the virus, including lockdowns, travel restrictions, the prohibition of public gatherings, and the closure of public institutions. These measures have had a huge impact on the delivery of judicial services and the justice system as a whole, as access to courts and prisons has been severely restricted. Access to justice is not just a fundamental right in itself; it is also an essential prerequisite for the protection and promotion of all other rights, including civil, political, cultural, economic, and social rights. Access to courts can be considered the inexorable pathway to justice. Anything that hinders the free movement of citizens in and out of the justice system has implications for the delivery of legal services, socio-economic development, inclusive prosperity, economic growth, and the welfare of a country's citizens. Access to courts promotes stability and political and economic liberalization by guaranteeing the opportunity for all people to seek protection and redress under the law. This is especially important for vulnerable groups, who often only have the justice system to rely on to protect and enforce their rights. The resilience of these communities is, therefore, dependent on the resilience of the overall justice system. Even in ordinary times, judicial systems, especially in developing countries, suffer from inefficiencies and inordinate delays in the processing and hearing of cases. Congestion and unreasonable delays in the court system are unfortunate realities of the judicial process in many parts of the world.

The COVID-19 crisis has resulted in increased delays and the lengthy adjournment of trials. Shelter-in-place orders have led to the shutting down of courts, postponement of trials, and delays of other judicial proceedings. Additionally, prison visits and the ability of police and judicial officers to inspect properties and crime scenes have also been negatively impacted by the pandemic. The need to prioritize safety has meant that courtrooms must observe social distancing measures, which has led to a shortage of available courtrooms, as some courtrooms are too small to enforce social distancing. Trials must be conducted in a manner that is not only safe but also observes constitutional safeguards. Some pandemicrelated measures have caused specific problems with criminal trials, including victims dropping out of sensitive sexual and domestic abuse cases, resulting in further persecution at the hands of the offenders. Many detention centers also suffer from overcrowding and uninhabitable conditions. This is especially the case for persons awaiting trial. One of the concerns when cases are delayed is the possibility of the misuse of the practice of plea bargaining. There is an increased tendency for people awaiting trial to plead guilty to escape the rigors of trial and long pre-trial detention periods, which have become more prevalent during the current crisis. There is a danger that prosecutors will take advantage of people's situations and force them to agree to guilty pleas in exchange for freedom, which could result in innocent people pleading guilty to avoid trial. It has been observed that some litigants in family matters have taken advantage of the pandemic to 
secure emergency court orders for temporary sole custody, citing safety concerns of the child. Some courts have also refused the filing of non-essential and nonemergency cases. When deciding whether to pivot to remote proceedings, officials need to consider all intended and unintended consequences and their likely impact on the rights of defendants. Of particular importance is the likelihood that the defendants' pre-trial detention period will be protracted. Other considerations include the actual length of any delays; the nature of the hearing, including the complexity of the case and the matter being dealt with; the need to call witnesses; the likely impact of the hearing on individual rights and deprivation of liberty; and the existence of impairments or other factors that could negatively affect the defendant's ability to participate effectively in court proceedings.

\section{Distancing and space}

As courts reopen, they are faced with logistical challenges in terms of complying with government health directives. Courts must adapt their physical spaces as well as entry protocols to adhere to safety guidelines, including installing acrylic barriers; providing staff with safety kits; offering masks to visitors; improving ventilation systems; taking temperature at courthouse doors; and adopting procedures to protect jurors (e.g., pre-screening them through questionnaires before bringing them into the courthouse). However, there is limited space in the courts, which means that adhering to social distancing (e.g., maintaining two meters of distance) is extremely difficult, considering the number of litigants, lawyers, court staff, and legal staff involved in the justice system. Moreover, some court infrastructure is old and cannot be adjusted or modernized with the technology necessary to meet the new standards. There is also the need for numerous other measures to enable courts to function in a safe environment, such as improved cleaning procedures and education of staff about how the virus spreads.

Courts have taken a number of measures designed to protect staff. These include advisory notifications on the restriction of trials, the implementation of telework arrangements, and the restriction of entry to courthouses or their closure altogether. The effects of the pandemic extend beyond the courtroom to a noticeable shift in some of the usual litigation trends, including (a) the promotion of alternative dispute resolution mechanisms, such as arbitration and mediation; and (b) a fall in the number of new claims, which could be due to the de-prioritization of less important cases or because people are waiting for the end of the pandemic to file cases.

\section{Specific problems with criminal trials}

For countries that have jury systems, there are concerns about exposure and operational issues involved in maintaining two meters of distance among jurors. These issues can also lead to distracted jurors, which could result in unsound judgments if jurors are more concerned about their health and safety than the case before them. However, the current circumstances could also incentivize prosecutors to 


\section{Muna Ndulo}

drop minor charges, although this is quite difficult to evaluate, since many justice departments may not have proper records of cases they decided not to pursue. Human rights that guarantee a speedy trial, liberty, an impartial jury, and right to counsel are at stake in many countries because of the pandemic. People's rights may be compromised due to inadequate technology, limited access to jurors, lack of digital skills, low levels of literacy, and lack of access to digital services, especially among women and vulnerable groups. For example, the use of technology in courts may not always be tailored to the needs of the most vulnerable users of the justice system, such as people with learning disabilities. Emergency orders may also delay speedy trials, leading to more time in prison and delays in bail hearings. The unemployment crunch, resulting in a lack of bond money, further contributes to prison overcrowding.

\section{The impact of COVID-19 on women and girls and their access to the justice system}

\section{Women, girls, and COVID-19}

While the COVID-19 pandemic has had a devastating impact on all people around the world, it has especially affected the lives of women and girls. Crises, conflict, disasters, and unrest are always linked to an increased incidence of violence against women and girls, including intimate partner violence. The United Nations (UN) has observed that policies such as lockdowns, quarantines, stay-at-home orders, and travel restrictions adopted by countries in response to the pandemic increase the risks of gender-based violence (GBV) (Vaeza, 2020). The United Nations Population Fund (UNFPA) projects that millions of new cases of GBV will occur globally for every year that lockdown measures continue (UNFP, 2020). The drivers of violence include increased levels of economic insecurity and lengthy periods of quarantine. Data from multiple countries already show an alarming increase in demand for helplines, protection orders, and emergency shelters.

A UNFPA report further observed that COVID-19 disruptions would delay the implementation of programs meant to prevent other forms of GVD, including child marriages in countries where they are prevalent. Poverty is a known driver of child marriages, so pandemic-related economic stress may increase the risk of families marrying off their daughters to alleviate the perceived burden of caring for them. The increase in GBV is likely to push back fragile progress made on gender equality, strain already overburdened justice systems, and exacerbate the economic impact of COVID-19. Access to judicial services requires financial resources to pay for lawyers and court fees, which disproportionally affects the poor and vulnerable groups, including women, children, juveniles, and persons living with disabilities. Reports indicate that the pandemic has made it harder for especially women to access judicial services, ${ }^{4}$ and it has resulted in rising GBV and discriminatory laws that have affected the lives of women and other vulnerable groups, including lesbian, gay, bisexual, transgender, queer, and intersex (LGBTQI) individuals. 
Due to lockdown and unemployment, domestic violence has increased significantly around the world. Unemployment increases tensions in the household and relationships, which can lead to violence. A lack of privacy in shared accommodation can also lead to an increase in the reporting of violent incidents. An increase in caregiving responsibilities, such as during the current crisis, without a corresponding increase in protection for caregivers exacerbates the situation. In its special submission to the UN Special Rapporteur, Human Rights Watch identifies the following categories of vulnerable women: domestic workers, older women, women working from home, women without technology, women facing housing issues, and women facing overlapping discrimination or inequalities.

\section{Shelter-in-place orders and escaping violence}

Shelter-in-place orders have in some cases undermined women's ability to respond to domestic violence by confining them to their homes. The threat has been acknowledged by the UN Secretary-General António Guterres, who stated that while "we know lockdowns and quarantines are essential to suppressing COVID19 ... they can trap women with abusive partners" (Guterres, 2020a, para. 8). In another presentation, the Secretary General stated that court closures have made it more difficult for women to obtain protection orders against their abusers, and that "gender equality and women's rights are essential to getting through this pandemic together, to recovering faster, and to building a better future for everyone" (Guterres, 2020b, para. 19). The COVID-19 pandemic has created a toxic brew of circumstances that have directly and indirectly affected almost every group in the world. Moreover, violence against women increases during emergencies, and the current pandemic is no exception (UN Women, 2020). Gendered disadvantages have increased at an alarming rate during the crisis, and these disadvantages have been acknowledged as a "shadow pandemic" (Mlambo-Ngcuka, 2020, para. 1) by the executive director of UN Women, Phumzile Mlambo-Ngcuka. She observed further: "Confinement is fostering the tension and strain created by security, health, and money worries. And it is increasing isolation for women with violent partners, separating them from the people and resources that can best help them" (para. 3). Additionally, the COVID-19 crisis puts women and children at further risk of violence, as it restricts women's ability to deploy their usual safety strategies, such as staying with relatives or sending children out to play when the level of abuse is escalating.

The COVID-19 pandemic has disrupted or severed many social, legal, and educational support networks. For example, school closures have made young people vulnerable to abuse by family and other household members, and teen pregnancies and early marriages have increased. Communication restrictions by their abusers have meant that many women have been unable to access support systems, and the closure of courthouses and/or delayed court hearings have made it difficult for women to obtain legal redress. It has been widely acknowledged that some measures countries have put into place to mitigate the socio-economic impact of the pandemic, including restrictions on movements and isolation 
measures, have had an adverse effect on especially women (UN Department of Global Communications, 2020).

Among the measures implemented around the world to mitigate the effects of the pandemic, some have restricted court operations to prevent the spread of the virus, which has had a detrimental impact on those seeking timely justice and resolution. In Uganda, officials suspended all court hearings and appearances for 32 days, effective on March 20, 2020 (Supreme Court of Uganda, 2020). While courts continued to hear urgent cases, judgments and rulings were issued to parties online or through email. Judiciary staff were banned from traveling except under exceptional circumstances (Karugaba, 2020). Moreover, the Chief Justice in South Africa announced through a circular that only urgent matters related to disaster management could be heard during the extended lockdown period. Both criminal and civil trials were postponed, and the circular encouraged parties to try to settle matters out of court. For example, the parties already in agreement may request the Registrar of the High Court to bring their case before a judge to grant a consent order (Mogoeng, 2020, paras. 6-7). ${ }^{5}$

The shutting down of courts has made it more difficult for women to protect themselves from their abusers. Many courts have restricted their functions to urgent matters, limited access to courthouses, and imposed online filing requirements. For example, in the Democratic Republic of the Congo, courts provided only minimal services, with no public hearings and no witnesses for cases that needed a hearing.

Groups dealing with domestic violence have had to file protection orders for domestic abuse victims remotely and use innovative ways to contact victims in cases when the primary means of communication are controlled by the abuser. In normal circumstances, victims can seek help at shelters and through colleagues, families, and other support systems. Such support is often no longer available, and many domestic violence groups have had to find innovative solutions to file cases and contact victims, such as working with local courts to set up e-filing for protection orders, relying on neighbors and delivery persons to contact victims, and setting up support hotlines through text-messaging.

Domestic workers around the world, most of whom tend to be women, have also been negatively impacted by COVID-19. The U.S. National Domestic Workers Alliance survey of late March found that almost three-quarters of domestic workers in the United States have lost their jobs because of the pandemic (Schwabish \& Anderson, 2020). Globally, with schools closed, many have taken on added household work and childcare duties. They have also been subjected to increased abuse and face economic insecurity because of delayed wages and the possibility of deportation. Lebanon and Jordan are hosts to some of the largest populations of migrant domestic workers in the world. In Lebanon, hospitals have refused to test undocumented workers for COVID-19 without their employers' consent. Although documented, some live-in migrant domestic workers in Lebanon have had their identification documents seized by abusive employers. A 2016 International Labour Organization (ILO) study found that out of 1,200 employers surveyed in Lebanon, more than 94\% withheld their workers' passports 
(ILO, 2016). The ILO reports that the COVID-19 crisis has increased the price of food and basic hygiene products, making it difficult for migrant workers to access a balanced and healthy diet. The ILO has also found that the pandemic has increased xenophobia across the country (Stoevska, 2020).

The COVID-19 pandemic has led to an environment in which human trafficking thrives. According to the National Center for Missing and Exploited Children in the United States, there was a 90\% increase in "online enticements" between January and June 2020 (O'Donnell, 2020). School closures, unemployment, food insecurity, homelessness, and travel restrictions all tend to be perfect catalysts for enticing and exploiting victims. The vacuum left by school closures is filled by predators who offer food, security, and money in exchange for abuse and exploitation. Human trafficking has also been impacted by court closures. Limited legal services result in delayed or abandoned evidence collection and limited translating and interpreting services. Efforts aimed at combating human trafficking have also been negatively impacted by the pandemic. Traffickers benefit from border closures because of delayed, reduced, or lack of communication between neighboring countries. A report by the Organization for Security and Cooperation in Europe's Office for Democratic Institutions and Human Rights (OSCE ODIHR) reports that 102 countries are struggling to provide trafficking survivors with basic services and support during the pandemic (OSCE ODIHR \& UN Women, 2020).

The COVID-19 pandemic has had an especially negative effect on the reproductive, emotional, and mental health of women (Mittal \& Sigh, 2020). Women have missed regular health visits because of the crisis, including breast cancer screenings and reproductive health treatments. The pandemic has also caused delays in the contraceptive supply chain, affecting access to birth control pills, condoms, and other reproductive medication. For example, lockdowns in Nepal and India have forced clinics operated by Marie Stopes International— the largest provider of family planning services in India outside the public sector- to close. A new study conducted by investigators from CARE, a non-profit international aid organization, has found that while almost nobody is spared from the anxiety, worry, and overall emotional fatigue of the pandemic, women are almost three times as likely as men to report suffering from significant mental health issues that are attributable to the current crisis (Kluger, 2020). A recent Kaiser poll shows that $53 \%$ of women who responded report a significant negative impact on their mental health, compared with only $37 \%$ of men (Panchal et al., 2020).

\section{Approaches to deal with challenges facing women}

A number of approaches are being taken to mitigate the impact of the pandemic on women around the world. These include (i) increasing the use of hotlines for reporting incidents related to GBV; (ii) enabling chat-based reporting tools to make it easier for victims who lack privacy to seek help; (iii) training personnel to deal with cases involving GBV; (iv) providing alternative options for shelters; (v) leveraging ICT to allow victims and judges to communicate directly with each 
other and enable special protection units to carry out interviews and psychological evaluations remotely; (vi) using social media platforms to share information on legal support available in cases of domestic violence and to refer victims to emergency hotlines; and (vii) creating remote applications for issuing protection orders and filing complaints through hotlines. In Australia, policymakers have enacted changes to the criminal code that made it possible to submit restraining orders online, and they increased the penalty and extended the limitation period for prosecuting breaches of restraining orders.

\section{Pandemic-related measures taken in the justice sector and their impact on human rights: An evaluation}

While measures are needed to protect litigants, court personnel, and the public from exposure to COVID-19, some measures taken by countries have posed serious human rights concerns. This section examines some of these concerns. In response to the COVID-19 pandemic, prisons and detention centers across the world have been limiting or banning visits. These measures are no doubt understandable given the need to protect detainees, prison staff, and court personnel from the virus, but they have also interfered with the right of detainees to access essential services, including legal assistance. Restrictions and bans on inperson visits make defendants increasingly reliant on telephones and other forms of remote communication to maintain contact with their lawyers and families. In many countries, telephone services in prisons are not free, and the telephone infrastructure in many developing countries is not well developed, making it difficult for defendants to access their legal support. In most cases, this will mean that defendants are disincentivized, if not outright prevented, from communicating with their lawyers and families. There is also a risk that a reliance on remote communication will undermine the quality of legal assistance. Restrictions on the frequency and length of telephone calls, for example, could affect the ability to provide and obtain legal advice, and the lack of in-person meetings may make it harder for lawyers to establish a good rapport and working relationship with their clients. Moreover, video-link hearings can make it harder for lawyers and clients to communicate discreetly during hearings, and there are concerns about the confidentiality of video-based consultations between defendants and their lawyers before and during hearings. A fear that someone may be listening in during consultations impedes honest communication between lawyers and their clients.

Digital communication means that the parties are not going to be in the courtroom in person. The physical absence of defendants from the courtroom is likely to have an impact on their ability to participate effectively in their own criminal proceedings. This is a particularly serious challenge in cases where the defendant is unrepresented by a lawyer. Without legal assistance, defendants are likely to find remote hearing isolating, stressful, and disorienting. The poor quality of video conferencing infrastructure in many countries, especially developing countries, will also mean that litigants could find it difficult to follow and understand the proceedings, and they could even be prevented from observing the courtroom 
in its entirety. This deprives parties, lawyers, judges, and juries of the opportunity to read non-verbal clues from others in the courtroom, which is often important for lawyers to mount an effective defense.

\section{Technology and its implications for privacy}

With video conferencing, privacy is always an issue. The possibility that outsiders may find a way to listen in on hearings poses important privacy and security concerns, and improper access to digital court records and the interruption of internet services could stall or derail court processes. In addition, judges and staff may lack the necessary training to fully take advantage of new technologies, and lack of access to or inappropriate use of technology could hamper efforts to speed up trial proceedings. Even scheduling a date to enter a plea by video from prison can take three or four weeks, as the entire prison system may have a limited number of video links. Also, there may not be enough staff available to accompany prisoners to and from communication facilities.

There are also concerns about how to adequately protect witnesses testifying over video and how to ensure they are not coached, intimidated, or otherwise compromised. Limiting the number of people who can come to the courtroom may have the adverse effect of creating significant barriers for people seeking to use courts to protect or defend themselves and their rights. Not everyone involved in the justice system has access to or the ability to use the technology required to communicate electronically with the courts. This is especially true in domestic violence cases, where the accused could still be present in the same household as the victim.

Another challenge with remote hearings is how to ensure equal access to information for all parties. It can be particularly challenging for defendants to access information when files can only be accessed at a specific location (e.g., the courthouse or police station) or need to be brought to detention centers. Travel restrictions and the closure of certain facilities (e.g., the courthouse) could have a significant impact on the right of access to information, particularly for defendants in detention. Remote procedures have implications for the rights of all defendants, especially vulnerable defendants and those who need access to special services such as interpretation and translation. Defendants with mental impairment, in particular, face serious barriers to effective participation in most normal court settings. Depending on the defendant and the type of impairment, remote justice procedures could severely worsen these challenges, making it even more difficult for them to understand and follow court proceedings. There are similar challenges for defendants with other language-assistance needs, who face additional barriers to communication.

\section{Human rights implications of remote hearings in criminal trials}

Most countries' constitutions or laws guarantee the right to a public trial and the right to confront witnesses during trial. These are central provisions in all 
human rights conventions, including the International Covenant on Civil and Political Rights and the Universal Declaration of Human Rights. These rights are designed to ensure the rigorous testing of evidence presented in court against a defendant. Efforts to introduce digitization in the judicial process, especially for key parts of a trial such as criminal adjudication, could jeopardize the rights of defendants and victims alike.

On the other hand, technological innovations can greatly improve court procedures. In courtrooms worldwide, video conferencing is being implemented as a way to speed up proceedings. The use of video conferencing allows numerous users to express their thoughts in a more naturally occurring atmosphere (e.g., their homes), and it can improve the protection of witnesses. If a prisoner is known to be violent, it could be safer to hold trials and hearings remotely, with the prisoner attending proceedings in jail through a video link. Moreover, digital communication can improve the speed and efficiency of court proceedings and help relieve the pressure of a large backlog in cases. Using video conferencing tools could offer a better solution than waiting for a specific date or period when police officers are available to bring suspects or parties to the courtroom. The challenge is to find the right balance between the advantages and disadvantages posed by technology.

\section{Delays and prison overcrowding}

In its report on preparedness, prevention, and control of COVID-19 in prisons and other places of detention, published on March 15, 2020, the WHO identifies people deprived of liberty, such as people in prisons, to be especially vulnerable to COVID-19. The report recommends that

[e]nhanced consideration should be given to resorting to non-custodial measures at all stages of the administration of criminal justice, including at the pre-trial, trial, and sentencing as well as post-sentencing stages. Priority should be given to non-custodial measures for alleged offenders and prisoners with low-risk profiles and caring responsibilities, with preference given to pregnant women and women with dependent children.

(WHO, 2020, p.4)

The Council of Europe anti-torture Committee's statement of principles relating to the treatment of persons deprived of their liberty in the context of the COVID-19 pandemic also reiterates that

[a]s close personal contact encourages the spread of the virus, concerted efforts should be made by all relevant authorities to resort to alternatives to deprivation of liberty. Such an approach is imperative, in particular, in situations of overcrowding. Further, authorities should make greater use of alternatives to pre-trial detention, commutation of sentences, early release, and probation; reassess the need to continue involuntary placement of psychiatric patients; 
discharge or release to community care, wherever appropriate, residents of social care homes; and refrain, to the maximum extent possible, from detaining migrants.

(CE, 2020)

Despite their benefits, governments and the courts will have to consider the impact of virtual hearings on the rule of law and the right to a fair trial. The risk of procedural unfairness during remote hearings in the United Kingdom was noted in the case Hyde and Murphy v. Nygate and Rayment (2020). In that case, the judge asserted that the risk affected both sides equally and that the parties were both well resourced and well placed to manage a remote trial. Another case in the United Kingdom, SC v. University Hospitals Southampton NHS Trust (2020), further explored the concept of fairness during remote hearings. Justice Johnson concluded that the requirement of fairness was satisfied when a remote hearing can, with careful management, take place in a way that is fair to all parties. The judge went on to say that the hearing could be conducted remotely in a way that was fair but stressed that this did not mean that it should be conducted remotely.

The UN Special Rapporteur on the Independence of Judges has suggested seven guidelines to ensure that court staff, prosecutors, and lawyers maintain functioning judicial systems during the current crisis (UN Human Rights, 2020). He recommends an immediate streamlining of justice services to prioritize essential cases and that the prosecution of minor, civil, or economic cases should be postponed. He also argues that the increased risk of COVID-19 infection in crowded prisons could be lowered if pre-trial detentions were minimized and political prisoners, minor offenders, and those who have served most of their terms were considered for early release. Judges, magistrates, public prosecutors, and their staff should be tested for COVID-19 regularly, given that they have to participate in hearings and interact with lawyers and other authorities and groups. Finally, he recognizes that innovation and online procedures are essential in the current environment, but lockdown and social distancing should not prevent the judicial system from guaranteeing due process.

\section{Conclusions and recommendations}

The COVID-19 pandemic has disrupted judicial operations worldwide. Courthouses have been closed, cases suspended, and trials postponed. However, courts in many countries were already in crisis before the current pandemic. Many were underfunded, operating with insufficient infrastructure, and generally behind the curve in technology adoption. Similarly, many countries' prison systems were overcrowded and insufficiently resourced. There are several ways the justice system could slow the spread of COVID-19, including by (i) reducing the number of people in prison; (ii) eliminating face-to-face contact (e.g., for attorneys and staff); (iii) making correctional healthcare more accessible; (iv) subsidizing phone calls; and (v) increasing the use of ICT. Nevertheless, the current 


\section{Muna Ndulo}

crisis may present an opportunity for the judiciary to implement technological solutions and streamline processes to ensure that cases are managed properly and in an efficient and timely manner.

Many litigants seem to prefer virtual court hearings because they can attend them without having to take a lot of time off work or find childcare. In some places, the pandemic has even led to bail reforms, easier documentation, and fewer non-appearances in courts. There is a need for the legal profession and the judiciary to look at the current challenges as an opportunity to "reskill and upskill by embracing technology" (Sikri, 2020). The COVID-19 pandemic is only one of many crises the world is likely to face in the coming years. It is, therefore, imperative that governments are prepared and create systems capable of mitigating the effects of future emergencies.

Going forward, policymakers need to focus on not only minimizing delays in the judicial system but also ensuring that courts safeguard the rights of all parties. Long-term planning should be more than about how to reopen courts and must include efforts to make them more efficient, more user-friendly, and better than before. One positive effect of the COVID-19 pandemic has been the courts' increased use of technology and their implementation of e-filing and video conferencing solutions, although human rights and privacy challenges remain. The Chief Justice in the United Kingdom has expressed doubts that the courts will operate in the same way as they did before the pandemic. He argues that many courts have found virtual hearings convenient and overall successful (Holland, 2020). ${ }^{6}$ The use of technology may also help alleviate the financial pressures on courts, but the question is, especially for developing countries, whether technology will widen or narrow the gap between the rich and the poor. It is imperative that governments and international development banks prioritize investments in technological infrastructure to ensure that poorer countries and communities also benefit from improved communication.

The authorities should ensure that post-COVID-19 courts are more robust and efficient by reducing paper-based requirements and fully embracing ICT solutions wherever possible. Additionally, increased use of ICT will hopefully reduce the incidence of lost files, destroyed records, etc. The courts in the post-COVID-19 era may be faced with a surge in litigation related to the pandemic. Cases related to failing businesses, divorce, consumer credit, evictions, debt collection, bankruptcy, and domestic disturbances are likely to increase substantially. While few courts will resume in-person-only hearings and proceedings, hearings only via video conferencing are also not a viable solution. Instead, a balanced approach is needed, and the current crisis can be an opportunity for judiciaries to leverage new technologies to streamline processes and reduce delays in the court system.

If courts are to take advantage of technological advances, they will require huge investments in infrastructure, including better bandwidth for e-courts, to be able to hold virtual sessions. Since many rural areas, especially in developing countries, do not have adequate internet connections or facilities, governments need to make internet services more accessible to ensure that everyone can access virtual court sessions (Murungi \& Tusiime, 2020). Additionally, 
people need to be made aware of available internet-based legal services. Access to technologies such as video conferencing and monitoring may not be available to all lawyers and, more importantly, litigants, and many people may lack the necessary skills to use new systems, or they may be uncomfortable using them. In countries with low levels of education, unfamiliarity with technology is likely to be high.

There is a need for increased financial support for services that address violence against women and girls. The experience of the COVID-19 pandemic has demonstrated the importance of digital connectivity and the role of digitally enabled solutions in facilitating access to justice and other healthcare, education, and government services. Limited access to the internet in most developing countries has prevented them from fully leveraging the benefits of improved connectivity. Some governments have taken short-term measures to alleviate connectivity constraints, but medium-term policies are also needed to expand digital infrastructure and adopt digital technologies targeting groups for which provision of services is not commercially viable.

Before the pandemic, the gender gap in internet and mobile phone usage was already significant. In the least developed countries, women are, on average, $30 \%$ less likely than men to use the internet. The increased reliance on digital services in almost all aspects of daily life, from healthcare and transportation to the justice system, has disproportionately benefited men. Continued digital exclusion of women will widen the gender gap in access to legal services.

Strategies are also needed for disseminating information about the challenges people face in accessing the justice system and tools available to help them overcome these barriers. Lack of access to information during emergencies such as the current COVID-19 pandemic can significantly hamper recovery efforts. It is, therefore, important that government institutions put measures in place that allow them to quickly and efficiently disseminate accurate information during emergencies. Civil society organizations should be supported because they can play a pivotal role in information dissemination and the provision of training that complement efforts by state institutions. Moreover, governments need to ensure that the most vulnerable people have the necessary legal support and access to judicial institutions by strengthening the provision of basic legal services that target the needs of these groups. Failing to do so risks deepening social and economic inequalities in society. Long-term judicial reforms are likely needed to effectively respond to the threats posed by the current pandemic and its economic fallout.

Worsening financial, family, and health conditions are likely to lead to an upsurge in violence against women and girls, and policymakers need to ensure that courts are able to address the problems confronting women and other disadvantaged groups. The COVID-19-induced recession and unemployment are liable to reduce people's ability to pay alimony and child support, requiring courts to enforce or amend earlier decisions. In addition, women may find it difficult to access social protection payments and other crisis-related benefits if they lack legal forms of identification, are excluded from public information initiatives, or lack the financial resources to seek legal assistance. 


\section{Muna Ndulo}

Women's financial constraints are likely to worsen, as the pandemic is likely to widen existing economic gender gaps, further limiting women's access to justice. The current crisis presents an opportunity to evaluate different strategies to improve women's access to judicial services. This will, however, require countries to implement monitoring and evaluating mechanisms to measure the impact on women of arrangements adopted to address the effects of the pandemic on judicial systems. Measures that have helped to narrow the gender gap in access to judicial services should be made permanent and scaled up as appropriate rather than being regarded as temporary and reversible. Since the measures outlined in this chapter would require increased funding, countries should be encouraged to include and mainstream expenditures related to domestic violence and the COVID-19 pandemic in national budgets.

\section{Notes}

1 Whether it relates to the enforcement of contracts, criminal justice, or the review of allegations of infringement of fundamental rights, courts are the engine of justice and vital for seamless interactions in the society.

2 Since the courts regulate the use of power within a democratic society, judicial powers are often expressed in constitutional provisions, with rigid restrictions on amendments. For example, the Constitution of South Africa from 1996 establishes the powers of the Judicature in Chapter 8, sections 165-180.

3 Texas Chief Justice Nathan Hecht is co-chair of the national Pandemic Rapid Response Team.

4 This is explored in greater depth in the UN Women's press release of May 21, 2020.

5 The directives were issued by the South African Chief Justice Mogoeng Mogoeng in terms of Section 8 (3)(b) of the Superior Courts Act 10 of 2013 for the Management of the Superior Courts During the Extended Lockdown Period, April 9, 2020. See Section D (ii) (11-12) of the Directive.

6 There are, however, also human rights and security challenges associated with remote hearings for judges, lawyers, defendants, and victims.

\section{Case law}

Hyde and Murphy v. Nygate and Rayment, EWHC 845 (Ch.) (2020).

SC v. University Hospitals Southampton NHS Trust, EWHC 1445 (2020).

\section{References}

Banda, T. (2019). Access to Justice in Zambia: Court Efficiency In Zambia. The Cornell Institute for African Development. https:/ecommons.cornell.edu/handle/1813/69970 Council of Europe (CE), European Committee for the Prevention of Torture and Inhuman or Degrading Treatment or Punishment (2020, March 20). Statement of Principles Relating to the Treatment of Persons Deprived of Their Liberty in the Context of the Coronavirus Disease (COVID-19) Pandemic. https://rm.coe.int/16809cfa4b

Dakolias, M. (1999). Court Performance Around the World: A Comparative Perspective. Yale Human Rights and Development Journal, 2(1), 87, Article 2. 
Guterres, A. (2020a). Make the Prevention and Redress of Violence against Women a Key Part of the National Response Plans for COVID-19. https://www.un.org/en/un-coronavirus-com munications-team/make-prevention-and-redress-violence-against-women-key-part

Guterres, A. (2020b). Put Women and Girls at the Centre of Efforts to Recover from COVID19. United Nations. https://www.un.org/en/un-coronavirus-communications-team/put -women-and-girls-centre-efforts-recover-covid-19

Holland, N. (2020). COVID-19 and the Courts: The Impact of Lockdown on Justice. McDermott Will Eु Emery. https://www.jdsupra.com/legalnews/covid-19-and-the-cour ts-the-impact-of-22359/

International Labour Organization (ILO) (2016, September 19). A Study of the Employers of Migrant Domestic Workers in Lebanon: Intertwined. https://www.ilo.org/wcmsp5/gro ups/public/---arabstates/---ro-beirut/documents/publication/wcms_524149.pdf

Justice Committee, House of Commons (2020, July 30). Coronavirus (COVID-19): The Impact on Courts. https:/publications.parliament.uk/pa/cm5801/cmselect/cmjust/519/ 51903.htm\#_idTextAnchor000

Karugaba, P. (2020, March 28). Uganda Legal Implications of COVID-19. Uganda Legal Information Institute. https://ulii.org/blogs/phillip-karugaba/28-march-2020/uganda -legal-implications-covid-19

Kluger, J. (2020, September 24). The Coronavirus Pandemic's Outsized Effect on Women's Mental Health Around the World. TIME. https://time.com/5892297/women-coro navirus-mental-health/

Mittal, S., \& Singh, T. (2020, September 8). Gender-Based Violence During Covid-19 Pandemic: A Mini-Review. Frontiers in Global Women's Health. http://www.frontiersin .org/articles/10.3389/fgwh.2020.00004/full

Mlambo-Ngcuka, P. (2020, April 6). Violence against Women and Girls: The Shadow Pandemic. UN Women. https://www.unwomen.org/en/news/stories/2020/4/statement -ed-phumzile-violence-against-women-during-pandemic

Mogoeng, M.T.R.M. (2020, April 16). Directives Issued by Chief Justice Mogoeng Mogoeng in Terms of Section, 8(3)(b) of the Superior Courts Act 10 of, 2013 for the Management of the Superior Courts during the Extended Lockdown Period [2020] ZARC 31. http://www .saflii.org/za/other/ZARC/2020/31.html

Murungi, E.M., \& Tusiime, D.T. (2020, May 4). COVID-19: Law and Technology: Why an Electronic Case Management System Is a Necessity in Uganda. Bowmans. https:// www.bowmanslaw.com/insights/covid-19-law-and-technology-why-an-electronic-cas e-management-system-is-a-necessity-in-uganda/

National Center for State Courts (NCSC). (n.d.). Coronavirus and the Courts. https://ww w.ncsc.org/newsroom/public-health-emergency

O'Donnell, B. (2020, July 16). COVID-19 and Missing \& Exploited Children. National Center for Missing $\mathcal{E}$ Exploited Children. https://www.missingkids.org/blog/2020/covid-1 9-and-missing-and-exploited-children

Organization for Security and Co-operation in Europe (OSCE) Office for Democratic Institutions and Human Rights (ODIHR), \& UN Women (2020, July 30). Addressing Emerging Human Trafficking Trends and Consequences of the Covid-19 Pandemic. Organization for Security and Co-operation in Europe. https://www.osce.org/files/f/d ocuments/2/a/458434_4.pdf

Panchal, N., Kamal, R., Orgera, K., Cox, C., Garfield, R., Hamel, L., Muñana, C., \& Chidambaram, P. (2020, August 21). The Implications of COVID-19 for Mental Health and Substance Use. Kaiser Family Foundation. https://www.kff.org/coronavirus-covid -19/issue-brief/the-implications-of-covid-19-for-mental-health-and-substance-use/ 


\section{Muna Ndulo}

Schwabish, J., \& Anderson, T. (2020, October). 6 Months in Crisis: The Impact of COVID19 on Domestic Workers. National Domestic Workers Alliance. https:/domesticwork ers.org/sites/default/files/6_Months_Crisis_Impact_COVID_19_Domestic_Workers _NDWA_Labs_1030.pdf

Sikri, A.K. (2020, April 11). Social Distancing Is Leading to Much Needed Judicial Reform. Sunday Guardian Live. https:/www.sundayguardianlive.com/legally-speaking /social-distancing-leading-much-needed-judicial-reforms

Stoevska, V. (2020, December 9). COVID-19 Is Driving up Food Prices All over the World. ILOSTAT. https://ilostat.ilo.org/covid-19-is-driving-up-food-prices-all-over -the-world/

Supreme Court of Uganda, Chambers of the Chief Justice (2020, March 19). Circular CJ/C.7, Court Proceedings. Guidelines on Conducting Criminal Sessions in Courts of Judicature During the Existence of Covid-19 Pandemic. https://judiciary.go.ug/files/ downloads/CJ\%20Guidelines\%20on\%20Criminal\%20Sessions.pdf

UN Women (2020). COVID-19 and Ending Violence Against Women and Girls. https://ww w.unwomen.org/-/media/headquarters/attachments/sections/library/publications/2020 /issue-brief-covid-19-and-ending-violence-against-women-and-girls-en.pdf?la=en\&vs $=5006$

United Nations Office of the Commissioner for Human Rights (UN Human Rights) (2020, April 22). UN Expert Outlines Urgent Steps to Ensure Justice Systems Are Not Paralysed by COVID-19. https://www.ohchr.org/EN/NewsEvents/Pages/DisplayNews.a spx? NewsID=25816\&LangID=E

United Nations Population Fund (UNFPA) (2020, April 28). New UNFPA Projections Predict Calamitous Impact on Women's Health as COVID-19 Pandemic Continues [Press release]. https://www.unfpa.org/pcm/node/24174

Vaeza, M.N. (2020, November 27). Addressing the Impact of the Covid-19 Pandemic on Violence Against Women and Girls. UN Chronicle. https://www.un.org/en/addressing -impact-covid-19-pandemic-violence-against-women-and-girls

World Health Organization (WHO) (2020, March 15). Preparedness, Prevention and Control of COVID-19 in Prisons and Other Places of Detention. World Health Organization Regional Office for Europe. https://apps.who.int/iris/bitstream/handle/10665/336525/ WHO-EURO-2020-1405-41155-55954-eng.pdf?sequence $=1 \&$ is Allowed $=y$ 